УДК 618.56-06:618.14-002]-07-036.-092/.6

DOI 10.11603/24116-4944.2021.1.12351

๑о. В. Булавенко, Л. Р. Остап'юк, В. О. Рудь

Віннищький національний медичний університет ілені М. І. Пирогова

\title{
ОПТИМІЗАЦІЯ НАДАННЯ МЕДИЧНОЇ ДОПОМОГИ ПОРОДІЛЛЯМ ІЗ ГНІЙНО- ЗАПАЛЬНИМИ ЗАХВОРЮВАННЯМИ НА ОСНОВІ ПАТОГЕНЕТИЧНОЇ МОДЕЛІ
}

Мета дослідження - застосування патогенетичної діагностично-лікувальної моделі при гнійно-запальних захворюваннях та сепсисі в рамках методу фрлуоресцентної спектроскопії.

Матеріали і методи. Сироватка крові осіб основної групи - 40 вагітних жінок, 180 породілей із післяпологовим ендометритом і 15 хворих на сепсис та контрольної - 40 здорових жінок із неускладненим перебігом післяпологового періоду. Методи дослідження: клінічні, лабораторні, біохімічні, інструментальні, метод фрлуоресцентної спектроскопії, математичностатистичні.

Результати дослідження та їх обговорення. У здорових людей спектри фрлуоресценції сироватки крові (СК) мають вигляд лямбдоподібних кривих з $\lambda \max$ в області 330,1-335,1 нм, що відповідають нормальному свіченню сироваткового альбуміну людини. При гнійно-запальних захворюваннях частина його зв'язуючих центрів блокується токсинами, тому в СК є наявні два типи молекул альбуміну: «нормальні» та «патологічні». Для вагітних жінок інтенсивність фрлуоресценції СК зростає не більше ніж на 30 \% порівняно з характеристиками 20 \% розчину альбуміну, величини яких взято за еталон. Для породілей контрольної групи не було виявлено зсуву $\lambda$ max. Інтенсивність фрлуоресценції перебуває в межах більше 0,81 відносних одиниць (в. о.) порівняно 3 IF 20 \% донорського альбуміну. Для породілей із післяпологовими ендометритами зафіксовано зниження інтенсивності флуоресценції СК нижче 0,81 в. о., а в особливо тяжких випадках - плавний довгохвильовий зсув спектра фрлуоресценції. Для хворих на сепсис характерне зниження інтенсивності фрлуоресценції на 70-80 \% від норми. В особливо тяжких випадках характерною є поява другого піку в довгохвильовій області.

Висновки. Запропоновано патогенетичну модель виникнення гнійно-запальних захворювань та сепсису. Обґрунтовано її ефрективність на основі дослідження спектрально-фрлуоресцентних характеристик сироватки крові хворих із гнійно-запальними захворюваннями та сепсисом. Запропоновано використання розчину альбуміну в комплексному лікуванні післяпологових гнійно-запальних захворювань та сепсису.

Ключові слова: гнійно-запальні захворювання; сепсис; патогенетична модель; метод фрлуоресцентної спектроскопії.

ОПТИМИЗАЦИЯ ПРЕДОСТАВЛЕНИЯ МЕДИЦИНСКОЙ ПОМОЩИ РОЖЕНИЦАМ С ГНОЙНО-ВОСПАЛИТЕЛЬНЫМИ ЗАБОЛЕВАНИЯМИ НА ОСНОВЕ ПАТОГЕНЕТИЧЕСКОЙ МОДЕЛИ

Цель работы - применение патогенетической диагностически-лечебной модели при гнойно-воспалительных заболеваниях и сепсисе в рамках метода фрлуоресцентной спектроскопии.

Материалы и методы. Сыворотка крови лиц основной группы - 40 беременных женщин, 180 рожениц с послеродовым эндометритом и 15 больных сепсисом и контрольной - 40 здоровых женщин с неосложненным течением послеродового периода. Методы исследования: клинические, лабораторные, биохимические, инструментальные, метод орлуоресцентной спектроскопии, математико-статистические.

Результаты исследования и их обсуждение. У здоровых людей спектры фрлуоресценции сыворотки крови (СК) имеют вид лямбдоподобных кривых с $\lambda \max$ в области 330,1-335,1 нм и соответствуют нормальному свечению сывороточного альбумина человека. При гнойно-воспалительных заболеваниях часть его связывающих центров блокируется токсинами, поэтому в СК имеются два типа молекул альбумина: «нормальные» и «патологические». Для беременных женщин интенсивность флуоресценции СК растет не более чем на 30 \% по сравнению с характеристиками 20 \% раствора альбумина, величина которого есть эталоном. Для рожениц контрольной группы не было выявлено смещения $\lambda$ тах. Интенсивность фрлуоресценции находится в пределах более 0,81 о. е. по сравнению с IF 20 \% донорского альбумина. Для рожениц с послеродовым эндометритом зафиксировано снижение интенсивности фрлуоресценции СК ниже 0,81 о. е., а в особо тяжелых случаях - плавный длинноволновой сдвиг спектра фрлуоресценции. Для больных сепсисом характерно снижение интенсивности фрлуоресценции на 70-80 \% от нормы. В особо тяжелых случаях характерно появление второго пика в длинноволновой области.

Выводы. Предложено патогенетическую модель возникновения гнойно-воспалительных заболеваний и сепсиса. Обосновано ее эфроективность на основе исследования спектрально-фрлуоресцентных характеристик сыворотки крови больных с гнойно-воспалительными заболеваниями и сепсисом. Предложено использование раствора альбумина в комплексном лечении послеродовых гнойно-воспалительных заболеваний и сепсиса.

Ключевые слова: гнойно-воспалительные заболевания; сепсис; патогенетическая модель; метод фрлуоресцентной спектроскопии.

OPTIMIZATION OF THE MEDICAL CARE TO WOMEN WITH POSTPARTUM PURULENT-INFLAMMATORY DISEASES ON THE BASIS OF THE PATHOGENETIC MODEL

The aim of the study - to use the pathogenetic diagnostic and treatment model for purulent-inflammatory diseases and sepsis within the method of fluorescence spectroscopy.

Materials and Methods. Blood serum (BS) of the patients of the main group - 40 pregnant women, 180 women with postpartum endometritis and 15 patients with sepsis and control group - 40 healthy women with uncomplicated postpartum period. Research methods: clinical, laboratory, biochemical, instrumental, method of fluorescence spectroscopy, mathematical and statistical. 
Results and Discussion. In healthy people the fluorescence spectra of BS have the form of lambda-like curves with $\lambda$ max in the range of 330.1-335.1 nm, corresponding to the normal glow of human serum albumin. In patients with purulent-inflammatory diseases part of its binding centers are blocked by toxins, so there are two types of albumin molecules in the BS: "normal" and "pathological". For pregnant women, the fluorescence intensity of BS increases by no more than $30 \%$ compared with the characteristics of $20 \%$ albumin solution, the values of which were taken as a standard. Shift of $\lambda$ max was not detected for women in the control group. The fluorescence intensity is in the range of more than 0.81 relative units (r.u.) compared to IF of $20 \%$ donor albumin. For women with postpartum endometritis, a decrease in the fluorescence intensity of the BS below 0.81 r.u. and in particularly severe cases $-a$ smooth long-wave shift of the fluorescence spectrum were detected. For patients with sepsis the decrease in fluorescence intensity by $70-80 \%$ of normal was detected. In particularly severe cases, second peak appeared in the long-wave region.

Conclusions. The pathogenetic model of purulent-inflammatory diseases and sepsis was proposed. Its effectiveness was substantiated on the basis of research of spectral-fluorescent characteristics of blood serum of patients with purulent-inflammatory diseases and sepsis. The use of albumin solution in the complex treatment of postpartum purulent-inflammatory diseases and sepsis was proposed.

Key words: purulent-inflammatory diseases; sepsis; pathogenetic model; method of fluorescence spectroscopy.

ВСтУП. Питання якості надання медичної допомоги в акушерській практиці є ключовим компонентом збереження репродуктивного здоров'я жінок. Адже воно уособлює збереження генофонду нації та забезпечує збереження належного стану здоров'я майбутніх поколінь. Тим не менше, сучасні передові медичні технології не завжди здатні забезпечити оптимальні умови для цього. За останні 25 років уже тричі змінювалося саме визначення сепсису і септичного шоку; кожні чотири роки йде оновлення міжнародного протоколу інтенсивної терапії при участі десятків провідних організацій і експертів [1]. Таким чином, актуальність проблеми очевидна і вимагає від лікарів усіх спеціальностей сучасних знань щодо раннього виявлення і своєчасної, ранньої цілеспрямованої терапії сепсису і септичного шоку в акушерстві [2].

Сучасні світові тенденції свідчать про постійне зростання поширеності абдомінального розродження [3-6]. Зокрема, частота кесаревого розтину в Україні в середньому становить $24 \%$ і більше, а в деяких приватних установах може сягати і 80 \% [7]. Частота виникнення ускладнень у ранньому післяопераційному періоді та в більш віддалені терміни перебуває в межах від 10 до $65 \%$ і на даний час не має тенденції до зниження [8, 9]. Можливими ускладненнями після кесаревого розтину можуть бути нагноєння післяопераційного шва, гематоми різної локалізації, перитоніт та сепсис [10, 11]. В той же час, за даними літератури $[12,13]$, кровотечі та інфекційно-запальні захворювання після оперативного розродження $\epsilon$ основними причинами материнської смертності.

Крім того, післяпологові ускладнення у віддаленій перспективі, за даними авторів [14], можуть стати причиною вторинного безпліддя у 4,3 \% випадків. Вітчизняні вчені (А. В. Бойчук і співавт., 2019) стверджують, що одним із ключових фракторів успішного настання вагітност $€$ стан ендометрія [15] в період вікна імплантації. Також хронічний ендометрит $є$ фоном для розвитку поліпів ендометрія, що мають негативний вплив на фертильність. Хронічний ендометрит сприяє розвитку локальної гіперплазії ендометрія у жінок репродуктивного віку, що може бути причиною зниження їх фрертильності, та підвищує ризик виникнення онкозахворювань $[16,17]$.

Ключовим моментом для ефективного лікування гнійнозапальних захворювань та сепсису є використання сучасних діагностичних методів, забезпечення індивідуального підходу та надання якісної медичної допомоги відповідно до сучасних принципів персоналістичної медицини.
3 метою покращення якості діагностики актуальним є розширення сучасного арсеналу діагностичних методів та пошук нових можливостей на стику різних наук. Перспективним на цьому етапі $€$ використання фрізичних методів дослідження. У нас є свій успішний досвід використання методу фрлуоресцентної спектроскопії (МФС) [18-20] для діагностики гнійно-запальних захворювань і сепсису, в тому числі й в акушерській практиці [21-23].

МЕТА ДОсЛІДЖЕННЯ - застосування патогенетичної діагностично-лікувальної моделі при гнійно-запальних захворюваннях та сепсисі в рамках методу фрлуоресцентної спектроскопії.

МАТЕРІАЛИ ТА МЕТОДИ. Клінічною базою дослідження було гінекологічне відділення № 2 Вінницького міського клінічного пологового будинку № 2. Експериментальною базою дослідження була лабораторія люмінесценції кафредри експериментальної фрізики Львівського національного університету імені Івана Франка. Термін проведення дослідження - 2015-2019 роки.

Дослідження проводили з використанням оптичних монохроматорів МДР-2 та МДР-12. Об'єктами дослідження були проби СК осіб основної та контрольної груп. Основні групи дослідження становили 40 вагітних жінок, 180 породілей із післяпологовими гнійно-запальними захворюваннями та 15 хворих на сепсис. Контрольну групу становили 40 здорових породілей із неускладненим перебігом післяпологового періоду.

Збудження СК проводили світлом із довжиною хвилі 280 нм, що відповідає області оптимального збудження свічення триптофранового амінокислотного залишку сироваткового альбуміну людини.

Методи дослідження: клінічні, лабораторні, біохімічні, інструментальні, МФС, математично-статистичні.

РЕЗУЛЬТАТИ ДОСЛІДЖЕННЯ ТА ЇХ ОБГОВОРЕННЯ. Перш ніж перейти до обговорення результатів дослідження СК хворих із гнійно-септичними ускладненнями в рамках МФС, коротко зупинимося на основній ідеї патогенетичної концепції діагностично-лікувальної моделі гнійно-запальних захворювань та сепсису. Вона ґрунтується на тому, що при захворюваннях, які супроводжуються ендогенною інтоксикацією, частина молекул альбуміну в крові хворих заблокована токсинами. У результаті в їх крові є наявні два типи молекул альбуміну: нормальні та заблоковані токсинами (патологічні).

Молекули альбуміну мають здатність до комплексоутворення. При захворюваннях, які супроводжуються 
ендогенною інтоксикацією, частина його зв'язуючих центрів стає заблокованою токсинами. У результаті ці молекули альбуміну втрачають здатність виконувати свої основні фрункції, а саме транспортну та детоксикаційну. I хоча загальна концентрація альбуміну в організмі може перебувати в межах норми, його реальна «ефективна» концентрація при цьому може значно знижуватися. Слід відзначити, що визначення «ефрективної» концентрації альбуміну неможливо провести сучасними загальноприйнятими методами діагностики, які в даний час широко застосовуються в лабораторіях закладів охорони здоров'я. Враховуючи патогенетичні зміни молекул альбуміну при ендогенній інтоксикації, ефективним моментом патогенетичного лікування є використання в комплексній терапії інфузій розчину альбуміну з метою поповнення запасу повноцінного альбуміну в крові хворих для забезпечення виконання його основних життєвих функцій. В той же час інфрузія розчину альбуміну погіршує синтез ендогенного альбуміну в організмі людини. Однак без цієї інфузії при наявності вираженої ендогенної інтоксикації організм самостійно не зможе ії подолати.

Основними показниками, які ми вивчали в рамках МФС, були величини інтенсивності фрлуоресценції (IF) та

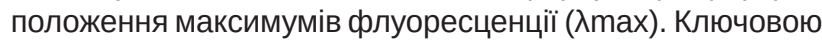
тезою діагностики, управління лікувальним процесом в рамках МФС та його корекції на основі запропонованої патогенетичної моделі є обстеження жінок у динаміці під час вагітності, при пологах та в післяпологовому періоді 3 метою вивчення та чіткого моніторингу спектральнофрлуоресцентних характеристик СК. У здорових людей спектри фрлуоресценції СК мають вигляд лямбдоподібних кривих із $\lambda_{\max }$ в області 330,1-335,1 нм залежно від віку. Це відповідає нормальному свіченню сироваткового альбуміну людини. Для породілей контрольної групи практично не було виявлено помітного зсуву $\lambda \max$ (величина цього показника коливалася в межах 330-337 нм). Інтенсивність же фрлуоресценції перебувала в межах 0,81-1,12 в. о. порівняно 3 IF 20 \% донорського альбуміну, величину якого було взято за еталон. Для вагітних жінок можливе зростання інтенсивності фрлуоресценції їх СК на 30 \% порівняно з IF 20 \% розчину альбуміну. Слід відзначити, що при вагітності в жінок має місце фрізіологічне збільшення об'єму циркулюючої крові, а рівень білків у ній майже не змінюється. За рахунок цього виникає фрізіологічна гіпопротеїнемія, а також зменшується взаємне концентраційне гасіння люмінесценції молекул альбуміну. Тому й зростає інтенсивність фрлуоресценції СК. У післяпологовому періоді, ймовірно, явища відносної гіпопротеїнемії можуть утримуватися, що спричиняє підвищення IF y деяких породілей до 1,11в. о.

При дослідженні спектрально-фрлуоресцентних характеристик СК породілей з післяпологовими ендометритами зафріксовано зниження інтенсивності фллуоресценції, а в особливо тяжких випадках - плавний довгохвильовий зсув положення максимуму $\lambda \max$. Отримані результати досліджень у динаміці належним чином корелюють зі станом хворих, а саме: при його покращенні відбувалося підвищення інтенсивності фрлуоресценції та короткохвильовий зсув смуги фрлуоресценції. При погіршенні стану - зниження інтенсивності та довгохвильовий зсув $\lambda$ max. Ця ознака $€$ прогностично несприятливою, що вимагає негайного призначення адекватного лікування після ії виявлення, оскільки такі зміни спектрів фрлуоресценції СК $€$ індикатором загрози щодо виникнення септичних станів у породілей.

У хворих на сепсис характерне зниження інтенсивності фрлуоресценції на 70-80 \% від норми. А в особливо тяжких випадках характерною є поява другого піку в довгохвильовій області, що зумовлений в основному вкладом «патологічних» молекул альбуміну.

На рисунку 1 представлено результати дослідження спектрів фрлуоресценції СК донора та хворої на тяжкий сепсис.

Видно, що у хворих такого типу (крива 1) інтенсивність їх фрлуоресценції може знижуватися на 70 \%, а довгохвильовий зсув спектрів фрлуоресценції СК може сягати 40 нм, що якісно узгоджується 3 даними дослідження in vitro [24] (розведення сироватки крові центрифугованими та нецентрифугованими посівами бактерійної культури). В той же час в області $\approx 335$ нм інтенсивність свічення, зумовлена вкладом в основному повноцінних молекул альбуміну, є дуже малою. Слід відзначити, що у тяжкому септичному стані існує гранична концентрація повноцінного альбуміну $X^{\star}$, яка забезпечує життєдіяльність пацієнтів. Отже, крива 1 на рисунку 1 відповідає $X \geq X^{\star}$. При зменшенні $X$ (зокрема, $X$ менше $X^{\star}$ ) може відбутися exitus letalis. В цьому полягає нова першопринципна концепція сепсису в рамках запропонованої нами патогенетичної моделі.

На рисунку 2 представлено результати досліджень у динаміці спектрів фрлуоресценції СК породіллі з післяпологовим ендометритом та хворої на сепсис. У породіллі був обтяжений соматичний анамнез (перенесений плеврит у 2013 р., сечокам'яна хвороба), обтяжений гінекологічний анамнез (хронічний аднексит). При пологах безводний період становив 6 год 30 хв. У післяпологовому періоді було виявлено анемію, протеїнурію, III ступінь чистоти піхви, розширення порожнини матки за даними УзД. Слід відзначити, що у неї були наявні фактори ризику виникнення післяпологового ендометриту. У даної

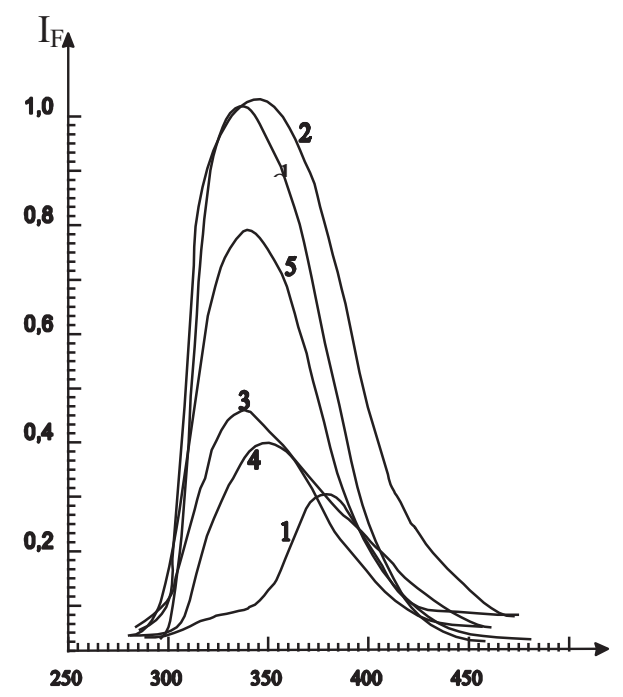

Рис.1. Спектри фрлуоресценції сироватки крові хворої на сепсис: 1 - 28.12.; 2 - 04.01.; 3 - 12.02.; 4 - 19.03.; 5 - 04.06. та СК донора (д). (340 nm - «нормальний пік», $380 \mathrm{~nm}$ - «септичний пік»). 


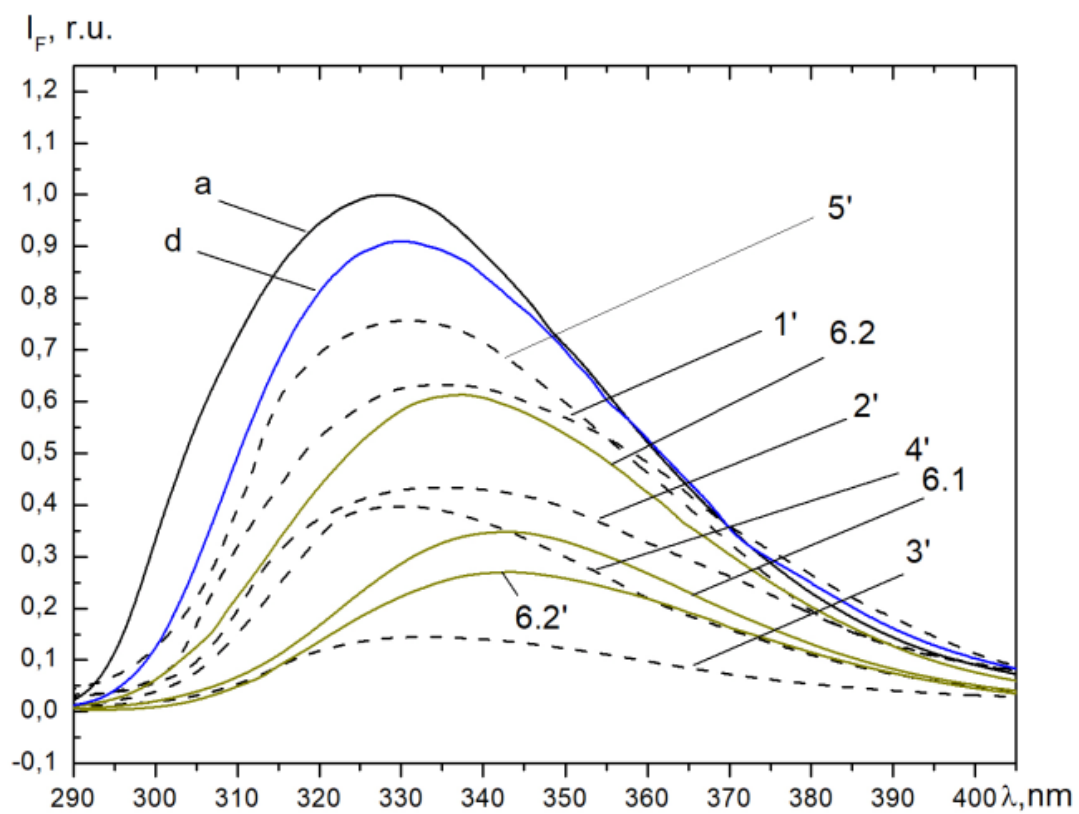

Рис. 2. Спектри фрлуоресценції сироватки крові породіллі з ендометритом в динаміці (6.1 - 14.02.2015; 6.2 - 17.02.2015, $6.2^{\prime}$ - 17.02.2015), породіллі з неускладненим перебігом післяпологового періоду (2), хворої на сепсис $\left(1^{\prime}, 2^{\prime}, 3^{\prime}, 4^{\prime}, 5^{\prime}\right)$ та 20 \% донорського альбуміну (а) $\left(\lambda_{36}=280\right.$ нм).

пацієнтки було виявлено значне зниження інтенсивності фрлуоресценції до 0,35 в. о. та помітний довгохвильовий зсув смуги фрлуоресценції. Після проведення мануальної вакуум-аспірації стінок порожнини матки, антибактеріальної та утеротонічної терапії стан хворої покращився. Після корекції лікування в наступному експерименті було зафріксовано помітне зростання IF CK цієї пацієнтки до 0,6 в. о. та нівелювання довгохвильового зсуву смуги фрлуоресценції. Слід особливо відзначити, що у випадку відтермінування мануальної вакуум-аспірації стінок порожнини матки на певний час стан пацієнтки погіршився б (крива 6.2') і значно наблизився б до стану хворої на сепсис (крива 3'). У цьому полягає особлива роль МФС в управлінні лікувальним процесом. Без отримання кривої 6.1 можна було б відтермінувати своєчасне проведення едективних лікувальних втручань і тим самим сприяти прогресуванню тяжкості стану пацієнтки аж до септичного стану. Таким чином, виявлені зміни спектральнофрлуоресцентних характеристик СК хворих на сепсис мають попередній доманіфестний характер: їх фріксують за 24-48 год до появи очевидних клінічно-лабораторних ознак суттєвої зміни загальносоматичного статусу хворих.

Слід відзначити, що при належному рівні лікування хворих на ендометрит (навіть у тяжкій фрормі) септичний стан практично недосяжний, якщо його зародження вчасно виявити в рамках МФС. При корекції лікувальної тактики можна було б призначати індузії $20 \%$ розчину альбуміну по 100-150 мл одноразово. При відсутності можливості контролю стану хворих у рамках МФС слід при погіршенні їх стану використовувати інсрузії $20 \%$ розчину альбуміну в їх комплексному лікуванні аж до покращення стану пацієнток. У випадку, якщо через певні причини не зафріксувати процес зародження септичного стану, він може розвиватись за одним сценарієм (рис. 2) або навіть за значно складнішим сценарієм (рис. 1). У країнах із низьким рівнем розвитку при неналежному лікуванні через можливий недостатній рівень знань та відсутність належних діагностичних можливостей у принципі септичні стани можуть виникати досить часто. У цьому випадку найбільш реальною перешкодою для їх виникнення можуть бути інфузії $20 \%$ розчину альбуміну, якщо своєчасно їх призначити.

ВИСновкИ. Запропоновано патогенетичну концепцію діагностично-лікувальної моделі гнійно-запальних захворювань та сепсису і дано нове визначення сепсису, що логічно випливає з даної моделі. Вивчено спектральнофрлуоресцентні характеристики сироватки крові вагітних жінок, породілей із неускладненим перебігом післяпологового періоду та хворих із післяпологовими ендометритами і сепсисом. Знання і розуміння цих закономірностей на основі запропонованої нами патогенетичної концепції дозволяють слідкувати за станом здоров'я жінок за допомогою МФС та при виникненні відхилень від норми корегувати лікувальний процес.

ПЕРСПЕКТИВИ ПОДАЛЬШИХ ДОСЛІДЖЕНЬ. Рекомендовано використовувати метод фрлуоресцентної спектроскопії у практичній діяльності закладів охорони здоров'я для діагностики гнійно-запальних захворювань та сепсису в акушерсько-гінекологічній практиці. При цьому актуальним $є$ створення банку даних спектрально-срлуоресцентних характеристик СК жінок і здійснення моніторингу змін їх спектрів фрлуоресценції СК при вагітності та в післяпологовому періоді. Такий підхід дозволить вчасно виявляти у кожної пацієнтки відхилення від норми. Це є кроком до впровадження моделей персоналістичної медицини в медичній практиці. 


\section{СПИСОК ЛІТЕРАТУРИ}

1. Barton J. R. Severe sepsis and septic shock in pregnancy / J. R. Barton, B. M. Sibai // Obstet. Gynecol. - 2012. - Vol. 120 (3). - P. 689-706.

2. Гріжимальський Є. В. Сепсис в акушерстві та гінекології / $€$. В. Гріжимальський // Медицина періопераційна. - 2018. - T. 2, № 1. - С. 13-21.

3. Огородник А. О. Кесарів розтин: віддалені наслідки - «ніші» післяопераційного рубця / А. О. Огородник, Ю. В. Давидова, Л. П. Бутенко // Перинатологія і педіатрія. - 2018. - № 1 (73). - С. 54-56.

4. Зростання частоти кесаревого розтину, як проблема сучасного акушерства / К. В. Тарасенко, А. М. Громова, В. М. Шафрарчук, Л. А. Нестеренко // Український журнал медицини, біології та спорту. - 2019. - № 5 (21). - С. 197-201.

5. Кесарево сечение. Проблемы абдоминального акушерства : рук. для врачей / В. И. Краснопольский [и др.] ; под. ред. В. И. Краснопольского. - 3-е изд., перераб. и доп. - М. : СИМК, 2018. - С. 224

6. Intervention thresholds and cesarean section rates: a time - trends analysis / A. Rose, E. A. Raja, S. Bhattacharya, M. Black // Acta Obstet. Gynecol. Scand. - 2018. - Vol. 97 (10). - P. 1257-1266.

7. Порівняльний аналіз ускладнень післяопераційного періоду при кесаревому розтину за M. STARK та модифрікованою методикою / І. 3. Гладчук, Ю.В.Герман, Т. А. Лунько, Д. О. Григурко // Актуальні питання педіатрії, акушерства та гінекології. - 2020. - № 2. - С. 69-75.

8. Вакалюк Л. М. Клінічно непрогнозовані результати кесаревого розтину / Л. М. Вакалюк // Ліки України. - 2014. - № 2 (19). - C. 19-20.

9. Analysis of emergency obstetric hysterectomy: the change of indications and the application of intraoperative interventions (in Chinese) / J. Chen, H. Cui, Q. Na [et al.] // Zhonghua Fn. Chan. Ke. Za. Zhi. - 2015. - Vol. 50 (3). - P. 177-182.

10. Skin preparation for prevention of surgical site infection after cesarean delivery: a randomized trail / I. M. Ngai, A. Van Arsdale, S. Govindappagari [et al.] // Obstet. Gynecol. - 2015. - Vol. 126 (6). - P. 1251-1257.

11. Maiwald M. Skin preparation for prevention of surgical site infection after cesarean delivery: a randomized trail / M. Maiwald // Obstet. Gynecol. - 2017. - Vol. 129 (4). P. 750-751.

12. Белокринская Т. Е. Профилактика септических осложнений в акушерстве: рекомендации МЗ РФ и ВОЗ 2015 г. / Т. Е. Белокринская, Н.И.Фролова // Российский вестник акушера-гинеколога. - 2016. - № 3. - С. 79-83.

13. Комбинированное лечение послеродовых кровотечений при кесаревом сечении с применением управляемой баллонной тампонады / С. В. Баринов, Я. Г. Жуковский,

\section{REFERENCES}

1. Barton, J.R., \& Sibai, B.M. (2012). Severe sepsis and septic shock in pregnancy. Obstet. Gynecol., 120 (3), 689-706. DOI: 10.1097/aog.0b013e318263a52d.

2. Grizhimalsky, E.V. (2018). Sepsys v akusherstvi ta hinekolohii [Sepsis in obstetrics and gynaecology]. Medytsyna perioperatsiina - J. Perioperative Med., 2 (1) 1-27. DOI: 10.31636/prmd.v2i1.2 [in Ukrainian].

3. Ohorodnyk, A.O., Davydova, Yu.V., \& Butenko, L.P. (2018). Kesariv roztyn: viddaleni naslidky - «nishi» pisliaoperatsiinoho rubtsia [Caesarean section: long-term consequences - «niches» of the postoperative scar]. Perynatolohiia
В. Т. Долгих [и др.] // Акушерство и гинекология. - 2015. № 1. - С. 32-38.

14. Дорофеєва У. С. Сучасні погляди на непліддя жінок старшого репродуктивного віку (огляд літератури) / У. С. Дорофеєєва, О. Г. Бойчук // Актуальні питання педіатрії, акушерства та гінекології. - 2020. - № 1. - С. 74-79.

15. Роль інфекційних збудників у жінок дітородного віку 3 гіперпластичними процесами ендометрія / А. В. Бойчук, Т. В. Верещагіна, В. С. Шадріна [та ін.] // Актуальні питання педіатрії, акушерства та гінекології. - 2020. - № 1. - С. 56-61.

16. Morphological features of uterine polyps in females of reproductive age / N. Y. Gorban, T. D. Zadorozhna, I. B. Vovk, I. V. Zhulkevych // Вісник наукових досліджень. - 2019. № 2. - C. 47-52.

17. Поліпи ендометрія в жінок репродуктивного віку сучасний етіопатогенетичний погляд на проблему (огляд літератури) / І. М. Нікітіна, К. В. Микитин, Н.В.Калашник [та ін.] // Актуальні питання педіатрії, акушерства та гінекології. - 2020. - № 2. - C. 111-118.

18. Пат. № 76953 Україна A61B 17/00 G01N 33/48, G01N 21/64 Спосіб ранньої діагностики гнійно-септичних ускладнень за допомогою методу фрлуоресцентної спектроскопії / Герич І. Д., Булавенко О. В., Остап'юк Л. Р., Волошиновський А. С., Мягкота С. В. ; заявник та патентовласник Вінницький національний медичний університет. № 201207441; заявл. 19.06. 2012; опубл. 25.01.2013, Бюл. № 2.

19. Herych I. Spectral-fluorescent properties of serum as a reliable marker for early diagnosis of sepsis / I. Herych, O. Bulavenko, L. Ostapiuk // J. Gynecol. Obstetrics. - 2014. Vol. 2 (5). - P. 71-74.

20. Ostapiuk L. Diagnostic and therapeutic model of sepsis and purulent-inflammatory diseases / L. Ostapiuk // Int. J. Clin. Med. - 2019. - Vol. 10. 577-595.

21. Обгрунтування доцільності застосування методу фрлуоресцентної спектроскопії в комплексній діагностиці післяпологового ендометриту / О. В. Булавенко, Л. Р. Остап'юк, В. О. Рудь [та ін.] // Здоровье женщины. - 2016. - № 3 (109). - С. 71-75.

22. Пат. України Метод ранньої діагностики гнійносептичних ускладнень після пологів за допомогою методу фрлуоресцентної спектроскопії / Булавенко, О., Остапюк, Л., Рудь, В., Волошиновський, А. С., Малуй, Т. С. ; заявник та патентовласник Нац. мед. ун-т ім. М. І. Пирогова. - 2019.

23. Prognostic model of the development of postpartum purulent-inflammatory diseases / O. Bulavenko, L. Ostapiuk, A. Voloshinovskii [et al.]// Int. J. Clin. Med. - 2020. - № 11. -P. 32-42.

24. Моделювання змін сироватки крові при різних захворюваннях та лікувальних заходах / О. В. Булавенко, І. Д. Герич, Л. Р. Остап'юк [та ін.] // Biomedical and biosocial anthropology. - 2013. - T. 20. - C. 8-14.

i pediatriia - Perinatology and Pediatrics, 1 (73), 54-56 [in Ukrainian].

4. Tarasenko, K.V., Hromova, A.M., Shafarchuk, V.M., \& Nesterenko, L.A. (2019). Zrostannia chastoty kesarevoho roztynu, yak problema suchasnoho akusherstva [Increasing the frequency of cesarean section, as a problem of modern obstetrics]. Ukrainskyi zhurnal medytsyny, biolohii ta sportu - Ukrainian Journal of Medicine, Biology and Sports, 5 (21), 197-201 [in Ukrainian].

5. Krasnopolskiy, V.I. (Ed.). (2018). Kesarevo secheniye. Problemy abdominalnogo akusherstva: ruk. dlya vrachey 
[Caesarean section. Problems of abdominal obstetrics: a guide for doctors]. 3rd ed., rev. and add. Moscow: Special Publishing House of Medical Books [in Russian].

6. Rose, A., Raja, E.A., Bhattacharya, S., \& Black, M. (2018). Intervention thresholds and cesarean section rates: a time - trends analysis. Acta Obstet. Gynecol. Scand., 97 (10), 1257-1266. DOI: 10.1111/aogs.13409.

7. Hladchuk, I.Z., Herman, Yu.V., Lunko, T.A., \& Hryhurko, D.O. (2020). Porivnialnyi analiz uskladnen pisliaoperatsiinoho periodu pry kesarevomu roztynu za M. STARK ta modyfikovanoiu metodykoiu [Comparative analysis of complications of the postoperative period in caesarean section according to $\mathrm{m}$. Stark and modified methodology]. Aktualni pytannia pediatrii, akusherstva ta hinekolohii - Actual Problems of Pediatrics, Obstetrics and Gynecology, 2, 69-75. DOI: 618.5-089.888.61048.77-06-084 [in Ukrainian].

8. Vakalyuk, L.M. (2014). Klinichno neprohnozovani rezultaty kesarevoho roztynu [Clinically unpredictable results of cesarean section]. Liky Ukrainy - Medicines of Ukraine, 2 (19), 19-20 [in Ukrainian].

9. Chen, J., Cui, H., Na, Q., Li, Q., \& Liu, C. (2015). Analysis of emergency obstetric hysterectomy: the change of indications and the application of intraoperative interventions (in Chinese). Zhonghua Fn. Chan. Ke. Za. Zhi., 50 (3), 177-182.

10. Ngai, I.M., VanArsdale, A., Govindappagari, S., Judge, N.E., Neto, N.K., Bernstein, J., \& Bernstein, P.S. (2015.) Skin preparation for prevention of surgical site infection after cesarean delivery: a randomized trail. Obstet. Gynecol., 126 (6), 1251 1257. DOI: 10.1097/AOG.0000000000001118.

11. Maiwald, M. (2017). Skin preparation for prevention of surgical site infection after cesarean delivery: a randomized trail. Obstet. Gynecol., 129 (4), 750-751. DOI: 10.1097/ AOG.0000000000001956.

12. Belokrinskaya, T.Ye., \& Frolova, N.I. (2016). Profilaktika septicheskikh oslozhneniy v akusherstve: rekomendatsii MZ RF i VOZ 2015 g. [Prevention of septic complicationsin obstetrics: recommendations of the Ministry of Health of the Russian Federation and WHO 2015]. Rossiyskiy vestnik akusheraginekologa - Russian Bulletin of Obstetrician-Gynecologist, 3 , 79-83 [in Russian].

13. Barinov, S.V., Zhukovskiy, Ya.G., Dolgikh, V.T., Medyannikova, I.V., Rogova, Ye.V., Razdobedina, I.N., ..., \& Makkoveyeva, Ye.S. (2015). Kombinirovannoye lecheniye poslerodovykh krovotecheniy pri kesarevom sechenii s primeneniyem upravlyayemoy ballonnoy tamponady [Combined treatment of postpartum hemorrhage during caesarean section using controlled balloon tamponade]. Akusherstvo i ginekologiya - Obstetrics and Gynecology, 1, 32-38 [in Russian].

14. Dorofeeva, U.S., \& Boychuk, O.G. (2020). Suchasni pohliady na nepliddia zhinok starshoho reproduktyvnoho viku (ohliad literatury) [Modern views on infertility in older women of reproductive age (literature review)]. Aktualni pytannia pediatrii, akusherstva ta hinekolohii - Actual Problems of Pediatrics, Obstetrics and Gynecology, 1, 74-79 [in Ukrainian].

15. Boychuk, A.V., Vereshchagina, T.V., Shadrina, V.S., Khlibovska, O.I., \& Koptyukh, V.I. (2020). Rol infektsiinykh zbudnykiv u zhinok ditorodnoho viku z hiperplastychnymy protsesamy endometriia [The role of infectious agents in women of childbearing age with endometrial hyperplastic processes]. Aktualni pytannia pediatrii, akusherstva ta hinekolohii - Actual
Problems of Pediatrics, Obstetrics and Gynecology, 1, 56-61. DOI: https://doi.org/10.11603/24116-4944.2020.1.11484 [in Ukrainian].

16. Gorban, N.Y., Zadorozhna, T.D., Vovk, I.B., \&Zhulkevych, I.V. (2019). Morphological features of uterine polyps in females of reproductive age. Visnyk naukovykh doslidzhen - Bull. of Sci. Res., 2, 47-52 DOI: https://doi.org/10.11603/24158798.2019.2.10267.

17. Nikitina, I.M., Mykytyn, K.V., Kalashnyk, N.V., Babar, T.V., Ikonopystseva, N.A., \& Kopytsya, T.V. (2020). Rol infektsiinykh zbudnykiv u zhinok ditorodnoho viku z hiperplastychnymy protsesamy endometriia [Endometrial polyps in women of reproductive age - a modern etiopathogenetic view of the problem (literature review)]. Aktualni pytannia pediatrii, akusherstva ta hinekolohii - Actual Problems of Pediatrics, Obstetrics and Gynecology, 2, 111-118. DOI: 10.11603/241164944.2020.2.11848 [in Ukrainian].

18. Herych, I.D., Bulavenko, O.V., Ostapiuk, L.R., Voloshynovskyi, A.S., Miahkota, S.V. (2013). Pat. № 76953 Ukraina A61V 17/00 G01N 33/48, G01N 21/64 Sposib rannoi diahnostyky hniino-septychnykh uskladnen za dopomohoiu metodu fluorestsentnoi spektroskopii [Pat. № 76953 Ukraine A61B 17/00 G01N 33/48, G01N 21/64 A method for early diagnosis of purulent-septic complications using the method of fluorescence spectroscopy]; zaiavnyk ta patentovlasnyk Vinnytskyi natsionalnyi medychnyi universytet. - № 201207441; zaiavl. 19.06. 2012; opubl. 25.01.2013, Biul. № 2 [in Ukrainian].

19. Herych, I., Bulavenko, O., \& Ostapiuk, L. (2014). Spectral-fluorescent properties of serum as a reliable marker for early diagnosis of sepsis. J. Gynecol. Obstet., 2 (5), 71-74. DOI: 10.11648/j.jgo.20140205.11.

20. Ostapiuk, L. (2019). Diagnostic and therapeutic model of sepsis and purulent-inflammatory diseases. Int. J. Clin. Med., 10, 577-595. DOI: https://doi.org/10.4236/ijcm.2019.1011047.

21. Bulavenko, O.V, Ostapiuk, L.R., Rud, V.O., \& Voloshynovskyi, A.S. (2016). Obhruntuvannia dotsilnosti zastosuvannia metodu fluorestsentnoi spektroskopii v kompleksnii diahnostytsi pisliapolohovoho endometrytu [Rationale of the method of fluorescence spectroscopy in complex diagnosis of postpartum endometritis]. Zdorovye zhenshchiny - Woman's Health, 3 (109), $71-75$ [in Ukrainian].

22. Bulavenko, O., Ostapiuk, L., Rud, V., Voloshinovskii, A.S., \& Malui, T.S. (2019). Pat. Ukrainy Metod rannoi diahnostyky hniino-septychnykh uskladnen pislia polohiv za dopomohoiu metodu fluorestsentnoi spektroskopii [Method of early diagnosis of postpartum purulent-septic complications using the method of fluorescence spectroscopy]; zaiavnyk ta patentovlasnyk Nats. med. un-t im. M. I. Pyrohova. 2019 [in Ukrainian].

23. Bulavenko, O., Ostapiuk, L., Voloshinovskii, A., Rud, V., Malyi, T., \& Rud, O. (2020). A prognostic model of the development of postpartum purulent-inflammatory diseases. Int. J. Clin. Med., 11, 32-42. DOI: https://doi.org/10.4236/ ijcm.2020.112004.

24. Bulavenko, O.V., Herych, I.D., Ostapiuk, L.R., Vashchuk V.V., Voloshynovskyi, A.S., \& Myahkota, S.V. (2013). Modeliuvannia zmin syrovatky krovi pry riznykh zakhvoriuvanniakh ta likuvalnykh zakhodakh [Modeling changes in serum for different diseases and medical events]. Biomedical and biosocial anthropology - Biomedical and Biosocial Anthropology, 20, 8-14 [in Ukrainian]. 